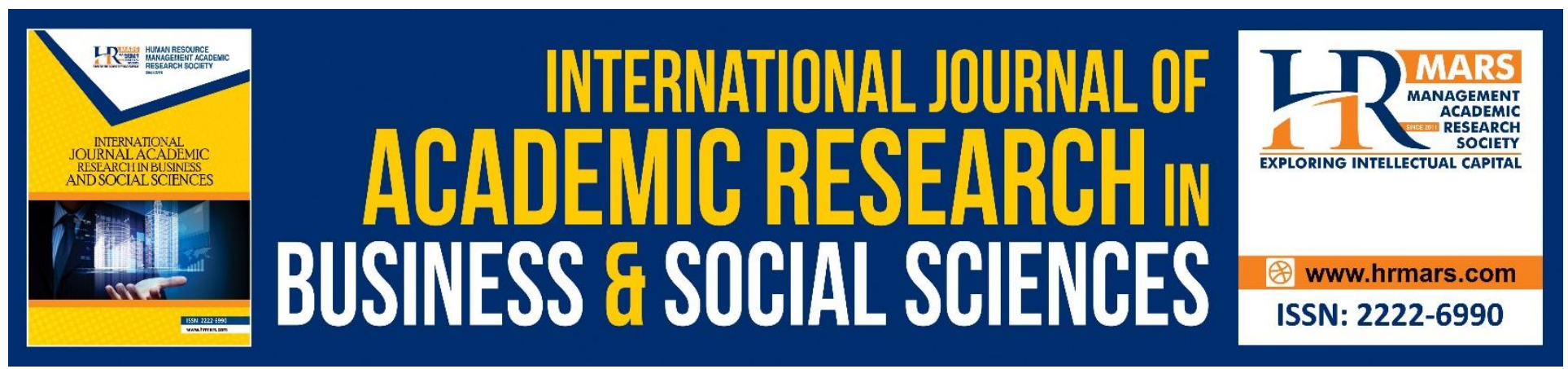

\title{
Analysis of Violent Act from the Islamic Spiritual Perspective
}

\section{Noor Shakirah Mat Akhir}

Norshabiha Ibrahim

To Link this Article: http://dx.doi.org/10.6007/IJARBSS/v9-i3/5797

DOI: $10.6007 /$ IJARBSS/v9-i3/5797

Received: 12 Feb 2019, Revised: 21 Feb 2019, Accepted: 1 March 2019

Published Online: 21 March 2019

In-Text Citation: (Akhir \& Ibrahim, 2019)

To Cite this Article: Akhir, N. S. M., \& Ibrahim, N. (2019). Analysis of Violent Act from the Islamic Spiritual Perspective. International Journal Academic Research Business and Social Sciences, 9(3), 1298-1306.

\section{Copyright: (C) 2019 The Author(s)}

Published by Human Resource Management Academic Research Society (www.hrmars.com)

This article is published under the Creative Commons Attribution (CC BY 4.0) license. Anyone may reproduce, distribute, translate and create derivative works of this article (for both commercial and non-commercial purposes), subject to full attribution to the original publication and authors. The full terms of this license may be seen

at: http://creativecommons.org/licences/by/4.0/legalcode

Vol. 9, No. 3, 2019, Pg. 1298 - 1306

http://hrmars.com/index.php/pages/detail/IJARBSS

JOURNAL HOMEPAGE

Full Terms \& Conditions of access and use can be found at http://hrmars.com/index.php/pages/detail/publication-ethics 


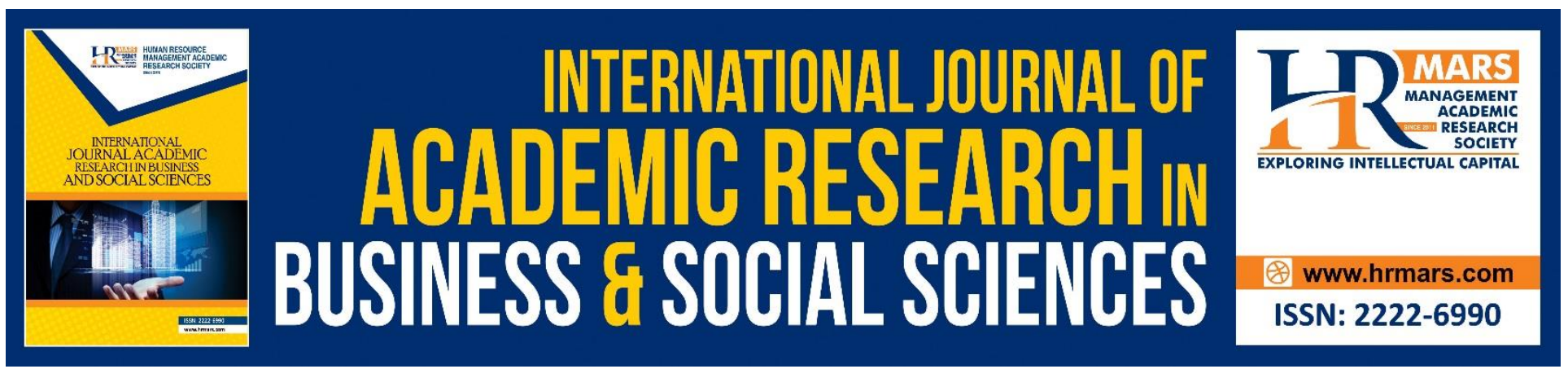

\title{
Analysis of Violent Act from the Islamic Spiritual Perspective
}

\author{
Noor Shakirah Mat Akhir \\ Norshabiha Ibrahim \\ School of Humanities, Universiti Sains Malaysia \\ 11800, Pulau Pinang, Malaysia.
}

\begin{abstract}
Violent behavior or act can be understood as action which conform to the definition of violence and may occur in various platforms, be it in religion, domestic or household, media, sexual and others that there are a plethora of studies that had been conducted on violence where numerous definitions were presented therewith. This study is therefore aimed to highlight the definition of violence from the perspective of Islam as well as other established perspectives. This study is qualitative in nature and involves literary review for the purpose of data collection. These varying definitions are analyzed from the spiritual Islamic perspectives. The findings of this study reveal that there are various aspects of violence itself with the spiritual imbalance in humans as the main contributing factor.
\end{abstract}

Keywords: Violence, Definition, Islamic, Spiritual, Imbalance

\section{Introduction}

Violence is one of the global issues often discussed especially when casualties or threats on the life of humans are involved. Never has the issues of violence attained worldwide coverage and discussed but the 9/11 disaster. Huge enough an issue that it triggered numerous global forums deliberating on the effects of the catastrophe; one of which is the UN Conference on Islamophobia in 2004. At present, the discourses revolves around the actions of individuals or countries to overcome violence or any other possible acts of terrorism. The concept of violence is widespread and involves facets of religion, domestic, media, sexual and others. Various definitions have been given to describe what terrorism is. Due to numerous types of violence there arise the need to identify the basis on which violence are triggered. Further discussions analyze various definitions of violence and observe the basis of each violence concerned. 
INTERNATIONAL JOURNAL OF ACADEMIC RESEARCH IN BUSINESS AND SOCIAL SCIENCES

Vol. 9, No. 3, March, 2019, E-ISSN: 2222-6990 @ 2019 HRMARS

\section{Definition of Violence}

The term violence can be assigned a simple meaning of a force. In a comprehensive definition it means "behavior involving physical force intended to hurt, damage or kill someone or something".

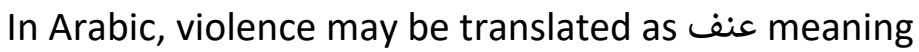

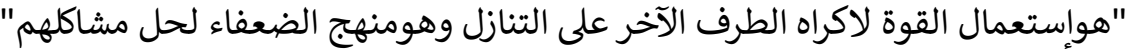

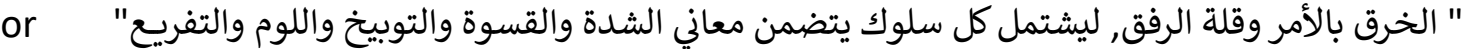

Translated into English, the above Arabic definition means something that goes overboard and devoid of compassion in any actions which gives an impression of powerful intent, forceful anger, evil and intense feelings (Manzur, 1979). While the term relating to violent acts which are often polemicized are irhab and jihad. The term irhab in al-Quran, means barrier to enemy assault (al-Anfal: 60). Jihad on the other hand means the efforts of a Muslim to counter evil, be it in the tangible form of human beings, devils and negative desires (al-Hajj: 78). The Islamic Research Academy of the alAzhar al-Sharif defines violence as "threatening those who live in peace, damaging their interests and elements of life, property, dignity, freedom and decency with the goal of doing damage and destruction on the face of the earth" (Zin, 2015). While the International Islamic Fiqh Academy defines violence as "Hostilities committed by individuals or groups or countries with the goal of committing harm to humanity, religion, blood, intellect, wealth and dignity. The acts include attempts to intimidate, to cause pain and suffering, threats, unlawful killings, and anything related to robbery and highway robbery. All these are acts of violence or threats committed by individuals or groups aimed at triggering terror among the public, threatening that they will be hurt or their lives, freedom and safety be exposed to risk and danger. It includes acts that jeopardize nature, public utilities, public or private property or exposing national or natural resources to risks." (Zain, 2015).

Al-Qaradhawi enlists the main features that lead a person to violence. Among them are obsessiveness, predominance of worldly affairs over commandments of God, unable to compromise when the situation necessitates it, prejudices and convenient accusation of infidelity. (Al-Qaradhawi, $1402 \mathrm{H})$

Violence from the Islamic perspective can be measured by the concept of wasatiyyah. The term wasatiyyah is a noun derived from the root word al-wasat which means the middle. In the holy book al-Quran, the Muslims are said to be the ummatan wasata (Al-Baqarah: 143) The guideline for humankind to always be in the wasatiyyah position are available in the al-Quran and Sunnah. Hence, any forms of act or situation that fall short of the directives of the holy Quran and the Sunnah is categorized as extreme and may lead to violence.

From the view point of the west, violence is understood as the using or the displaying of physical or emotional force to elicit violence. According to World Health Organization, violence refers to "the intentional use of physical force or power, threatened or actual, against oneself, another person, or against a group or community, which either results in or has a high likelihood of resulting in injury, death, psychological harm, maldevelopment, or deprivation."(Krug et al. 2002) In a broader sense, violence may take various forms. Violence can be understood as physical force against another party for the purpose of harming or injuring or even killing. Physical violence not only involves human but extends to animals and properties. Spiritual violence on the other hands includes provocation causing a reaction to emotions or persons. In short, violence may occur when human's mind is in disorder. 
Violence involving religion is identified as religious violence in English (Selengut, 2003). When scrutinized, these two words are contradictory in meaning. Religion on one hand, is a system which allows communion between the servant and his god; however when combined with violence, it becomes a polemic in terminology. Religious violence is not something new and indeed it exists in all religions contrary to popular stereotyping of Islam. Religion preaches peace but from the fold of history, religion too had been made the excuse for the outbreak of violence.

Religious society to date has had to deal with violence in the name of religion. One of the factors to the outburst of religious violence is conflicting views over an issue even against their own brethren in faith, much more against devotees from different beliefs system altogether. Religious violence comes from the mind of religion followers who are influenced by the ideas of bigotry and violence. Apart from religious violence, there are many other forms of violence such as media violence, including the print and electronic. Media violence refers to whatever violent acts highlighted in both media categories. (Yaacob, 2010). In addition sexual violence refers to harsh acts as well as sexual advances. The perpetrators would commit the act of fondling, kissing and molesting. (Shah, 2004)

Family or domestic violence may be understood as a deliberate act of torture or destruction of property. Family violence also refers to intentional act to harm other party physically. (Abbash, 1999) Family violence also extends to neglect of responsibility. Acts such as assault, touching, harassing, physical and mental abuse as well as sexual or any other acts of encroachment. According to Section 2 of the Domestic Violence Act, 1994, domestic violence refers to acts that consist of physical injury, coercion in sexual act, false imprisonment, damage to properties and acts intended to induce sadness and annoyance of a victim.

Workplace violence revolves around physical and psychological aspects. Among the features attributed to violence in the workplace are physical attacks, threats of use of power or strength, physical and psychological abuse or various forms of disturbances such as verbal, views, psychological and physical (Musri \& Martino, 2002)

Due to various definitions that are given to the terms violence coupled with its tie to various platforms and aspects, there is no specific clear cut definition of what violence is. What is violence? The absence of precise and specific definition gives rise to implications towards policy formulation of any particular country. The lack of specific definition too may amount to violation of human rights upon the parties or individuals labelled as terrorists. The present circumstances too shows that the understanding of what violence is; is often changing according to one's stand on a particular issue. Case in point Nelson Mandela; whom once was considered a terrorist but twenty over years later he was lauded at the international level when he eventually became a statesman.

\section{Analysis from an Islamic Spiritual Perspective}

From the previous discussions, violence is cruelty in the forms of physical, mental, sexual and neglect of responsibility, all of which are the result of human behaviors and decisions. Whereas religion is a system of belief and actions based on Holy Scriptures that is inherently associated with purity as it is based on one's faith in god. Factually, religion can bring people together, shape human thoughts, behavior and perception. Religion regulates human life quickly than any other elements that made up human identity. The power of spiritual and religious affirmation can change and move someone. 
In Islam, the implementation of worship is the medium of communion with Allah the creator and thereby can affect one's behavior.

\section{Balance of Soul}

Humans are assigned as khalifah in the face of earth (al-Baqarah: 30) being equipped with the faculty of thoughts that distinguishes them from other creations on earth. Intelligence enables the human to receive knowledge. (al-Ghazali, jld.1, t.t) According to al-Ghazali, basically, humans are made up of four main psychological elements which he terms as divine attributes, anger or fierceness, demonic attributes and animalistic behavior as well as desires. Divine attributes are positive traits that drive mankind to goodness, while the other three need to be controlled and properly channeled because they are constantly inciting mankind to do evil. The traits of devilish attributes are continuously rousing anger and desire to defeat the intellect, thereby controlling the three. (al-Ghazali, Jld3, t.t.) There are constant internal battles in humans between the divine, the devilish and the animalistic traits. As such, the state of being of the souls and their balances depend on the traits that becomes the leader and dominate the others in an individual. The soul can only be at peace and balanced when it is the divine traits that triumphs over the other three. This conflict is in an ever going mode and would be experienced by all humans, but only by way of faith, knowledge and good deeds that the souls can be calmed.

Balanced soul produces virtuous deeds. In Islam, it is the faith that motivates the acts of any individuals. Motivation, in light of definition is total inclination or the level of one's desire to act at any given time. When a person gets encouragement, he then has a strong desire to act towards achieving goals. "Motivation is a common word about the situation that causes a person to start an activity and try hard to get that goal achieved". (Munji, 1989) Therefore, without the encouragement in the form of faith, humankind would not be balanced according to the Islamic benchmark. The goal of every individuals according to Islam is to seek the pleasure of Allah.

In addition to intellect and common sense humankind is endowed with numerous internal potentials such as curiosity, fear and anxiety. All these elements are contributing factors that can affect the individual's behavior. If these factors are not controlled by faith then the individual would become a victim of pure desire. A balanced soul, produces actions that are in line with syariah. The balanced soul is achievable by purification process of the soul called the tazkiyat al- Nafs as advocated by Islam. This soul purification process includes mujahadah al-nafs, muhasabah al-nafs and muraqabah alnafs.

Tazkiyat means purification while soul or nafs as simplified by al-Ghazali means:

1. Encompass all the forces of anger and negative desires found in human beings that which are the causes for evil behaviors.

2. The essence of self or the substance in the human body itself.

Thus, tazkiyat al-nafs means "human self-purification or purification of the desires which is the cause of all reprehensible traits inherent in human beings". (Stapa, 1997) Tazkiyat al-nafs is instrumental in the personality formation of an individual. Allah says in surah al-Baqarah, verse 129; 
"O our Lord, send them an apostle from among themselves, who will recite unto them your revelations and teach them the contents of the Book and wisdom and purify them (hearts and minds). Thou art the mighty, the wise."

Tazkiayat al-Nafs is among those included in the main task of Rasulullah (peace be upon him) who said "Verily, I am sent to perfect good characters." (Musnad Ahmad bin Hanbal) By virtue of this hadith, it is clear that tazkiyat al- nafs is indispensable in the formation of good ethics and values in one. Through the process of tazkiyat al-nafs which aims to purge the decadent traits (al-takhalli) and replaced with virtuous attributes (al-Tahalli), the balanced soul shall be achieved.

The al-Quran also mentions three categories of nafs namely nafs al-mumtainnah, nafs al-lawwamah and nafs al-ammarah. This categorization does not mean that human being has three souls. It is not mentioned by nufus or anfus which is the plural of nafs when reference is specifically made to individual soul unless the souls in general is meant as exemplified in verse 7 of surah al-Takwir that means "...and when the souls are met with the body".

Nafs al-mutmainnah refers to calm and tranquil soul within god's pleasure and affection, contents with qada' and qadar, mentioning and remembering Him, longing for Him, feeling of proximity and confiding in Him. This soul also means belief in god's promises unto His servants. This is the type of a soul, upon the demise of its vessel body, be greeted with “ $O$ ' reassured soul, return to your Lord well pleased (thyself) and well pleasing unto Him, enter among my (righteous) servants and enter my paradise". (al-Fajar: 28-30)

Nafs al-lawwamah on the other hand (al-Qiyamah: 2) is often a self-criticized soul, regretful for one's lack of obedience in obliging the teachings and welfare or due to wrongdoing.

Whereas nafs al-ammarah (Yusuf: 53) is the type of soul that always pushes people towards evil (ammarah bi al-su') and always calls upon according to self-desires, which leads to misdemeanor, wickedness and falsehood.

Therefore there are three functions or desires in an individual, namely ammarah, lawwamah and mutmainnah. In other words, there are three forces that are always competing to dominate the others. What needs to be understood is that nafs (desire) are not perpetually bad. Islam does not demand that the nafs (desires) be crushed and eradicated because they are essential in humans' lives, without which, there would be no progress and prosperity in this world. Hence god made humans as His caliphs on the face of the earth and not His angles which are not endowed with desires. What Islam teaches is the control of nafs much so they do not derail from the right track and not total denial or abolishment. For example, humans should have the desire to eat but the desire should be controlled as to avoid excessive consumption of food, but just enough to enable them to worship Allah and not excessively harmful. What is meant by nursing or purging the heart by tazkiyat al-Nafs is the efforts to remove the nafs ammarah appetite from one's heart and soul. If nafs al-ammarah took dominance in the heart and soul of one, the person would be committing abominable acts. Nafs al-lawwamah on the other hand should be constantly upgraded to the next level. Here lies the importance of tazkiyat al-nafs process i.e in order to achieve a balanced soul, it wholly depends on which category of nafs that is controlling one from inside.

The word al-khuluq which means demeanor and al-khalqu which means occurrence or physical form are two words often used together. What belongs to al-khuluq is the internal form and the al-khalqu 
the external physical being. By analogy, when one is said to be of good conduct and good appearance, it means the person is good inside out, spiritually and physically. This is particularly so because humans are made up of two entities that is the body which is apparent to the naked eyes and the essence or soul that resides in the body and can only be discerned by the spiritual eyes. Both categories have respective body and form and behavior either good or bad.

Al-khuluq or demeanor is a pervasive behavior that which imbedded into the soul from which the deeds habitually come forth without the need for thoughts and consideration. If what comes out from the soul is good and commendable deed, according to reason and shara', then the said deed is called good moral (al-akhlaq al-mahmudah) and if otherwise, it is called bad manners (al-akhlaq almazmumah). (al-Ghazali, 1991)

\begin{tabular}{|l|l|l|l|l|}
\hline Level of soul balance & $\begin{array}{l}\text { Divine } \\
\text { attributes }\end{array}$ & $\begin{array}{l}\text { Fierceness } \\
\text { attributes }\end{array}$ & $\begin{array}{l}\text { Animalistic } \\
\text { traits }\end{array}$ & $\begin{array}{l}\text { Devilish } \\
\text { attributes }\end{array}$ \\
\hline Nafs al-mutmainnah & Dominating & Submit & Submit & Submit \\
\hline Nafs al-lawwamah & $\begin{array}{l}\text { Partial } \\
\text { dominating }\end{array}$ & $\begin{array}{l}\text { Partial } \\
\text { dominating }\end{array}$ & $\begin{array}{l}\text { Partial } \\
\text { dominating }\end{array}$ & $\begin{array}{l}\text { Partial } \\
\text { dominating }\end{array}$ \\
\hline Nafs al-ammarah & Submit & Dominating & Dominating & Dominating \\
\hline & & & & \\
\hline
\end{tabular}

Table 1: The stages of control and surrender of the internal elements in humans

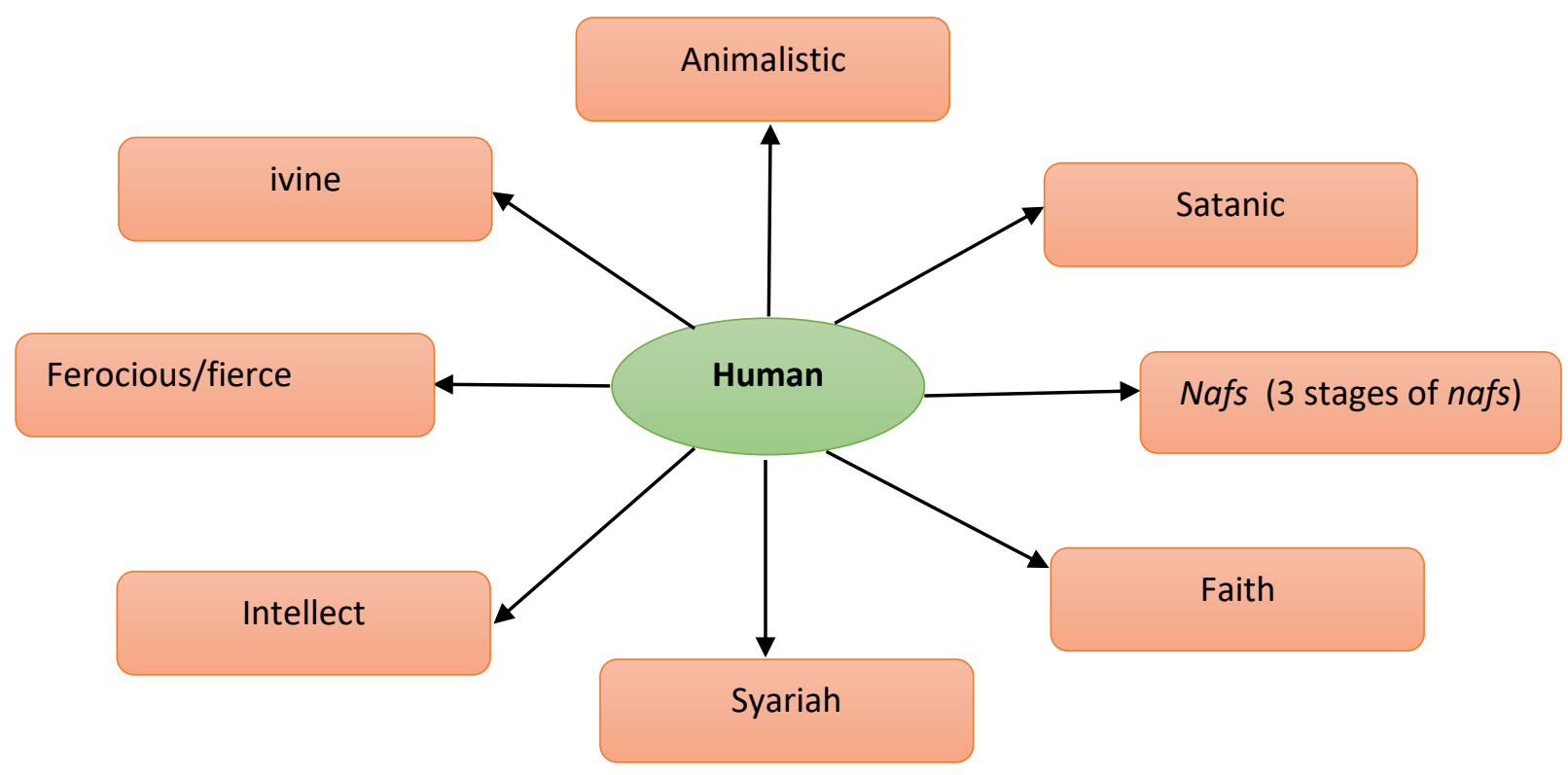

Figure 1: The dynamics of soul interaction

From the above discussions, it can be deduced that any violent act is due to a person's internal imbalance. The dominance of the bad traits over the others results in violent acts. Both diagrams 
above illustrate the internal situation or one's desires in various situations. The balanced soul is the solution to violent acts.

Centred on the definitions of violence from multiple facets, it shows that any violent behavior is a reflection of the internal imbalance of the offender. The tazkiyat al-nafs process which became one of the reasons of why the prophet was sent to humankind is the best method to balance those internal elements of human. The tazkiyat al-nafs process revolves around special and general worship to make the elements balanced hence producing syariah abiding actions.

The human formation that is made up of two beings; the physical and spiritual comes with two responsibilities. Responsibility to answer the demands of the spiritual body must be balanced with that of the physical one. What it means by balance is priority given to the spiritual body without neglecting the physical body. Islam advocates prioritizing the well-being of the spiritual body because it is the essence of what makes a human, since the outer body is just a shell, a vessel to house the essence; in this respect, the soul. Yet, spiritual heights will not be achieved if the shell body's requirements are neglected. This is in accordance with the human nature itself (Tabarrah, 1992).

\section{Conclusion}

Based on the above discussions, conclusion could be drawn that despite the existence of various types of violence, the core basis always falls on the aspect of internal imbalance of individuals who commit the acts of violence. Furthermore, from the above discussions it is clear that the spiritual aspect plays a major role in preventing violence and generate noble characters in line with Shari'a. Islam has truly established a true spiritual system in the efforts to prevent violence and solving problems. Tazkiyat al-nafs is a solution mechanism for violence that needs to be cultivated in life. This concept espoused by Islam can be used as a solid foundation in solving multitude of spiritual problems including violence. Violence should be viewed from the spiritual aspect and not just physical. Priority must be given to the internal aspect first because it is the essence of human being. The malfunction of any aspect will yield individuals with internal imbalance and consequently may give rise to violence elements in his or her action.

\section{Acknowledgements}

This study was funded by Fundamental Research Grant Scheme, Ministry of Education

Malaysia number 203/PHUMANITI/6711590

\section{Corresponding Author}

Noor Shakirah Mat Akhir

School of Humanities

Universiti Sains Malaysia

11800, Pulau Pinang, Malaysia.

Emel: shakirah@usm.my 
INTERNATIONAL JOURNAL OF ACADEMIC RESEARCH IN BUSINESS AND SOCIAL SCIENCES

Vol. 9, No. 3, March, 2019, E-ISSN: 222 2-6990 ¿ 2019 HRMARS

\section{References}

Al-Quran

Zin, A. M. (2015). Pendekatan Wasatiyyah Dalam Menangani Keganasan: Pengalaman Malaysia, Putrajaya: Institut Wasatiyyah Malaysia.

Afif Abd, Al-Fatah Tabbarah. (1992) Ruh Ad-Din Al-Islami, translated by Md. Akhir Hj. Yaacob, Kuala Lumpur: Bahagian Hal Ehwal Islam JPM.

Hanbal, A. I. (t.t). Musnad, 6 jilid, Mesir:al-Matba'ah al-Maymaniyyah.

Al-Ghazali. (1993). Ihya 'Ulum al-Din, jld. 3, Beirut: Dar al-Khair.

Al-Ghazali. ( t. t) Ihya 'Ulum al-Din, jld. 1, Beirut: Dar al-Ma'rifah.

Yadim, E. (2016). Terrorisme, http://www.yadim.com.my/v2/terrorisme/ (akses 3/7/18).

Hornby, A. S. (2000). Oxford Fajar Advanced Learner's English-Malay Dictionary, Fajar Bakti Sdn. Bhd. Manzur, I. (1979). Lisan al-Arab, Beirut; Dar al-Ma'arif.

Shah, I. M. (2004) Gangguan Seksual Di Tempat Kerja: Kajian Ke Atas Mangsa Dan Pelaku Di Sekitar Johor Bahru, Johor, Universiti Teknologi Malaysia: Johor.

Mohamad, M. (2002), Memahami makna keganasan, http://ww1.utusan.com.my/utusan/ (accessed on $3 / 7 / 18$ )

Musri, M., \& Martino, V. I. (2002), Panduan Bagi Pencegahan Tekanan DAN Keganasan Di Tempat Kerja, Kementerian Sumber Manusia.

Akhir, N. S. M. (2002). Nilai-nilai Kemanusiaan Dalam Pengurusan Sumber Manusia: Cabaran Dan Kaitannya Dengan Konsep Kualiti Dalam Islam, National Human Resource Management Conference Proceedings, Kedah: UUM.

Abbash, R. (1999). Keganasan Keluarga Dari Perspektif Psikologi, Jurnal Kebajikan, vol. 21, no. 2, www.kukum.edu.my

Selengut, C. (2003). Sacred Fury: Understanding Religious Violence, United Kingdom, Altamira Press. Munji, S. H., \& Redzuan, R. (1989), Pengantar Psikologi, Fajar Bakti: Kuala Lumpur.

Stapa, Z. (1997), Akidah dan Tasawuf, Bahagian Hal Ehwal Islam, JPM.

Yaacob, Z. (2010). Pengaruh Keganasan Dalam Media Terhadap tingkah Laku Agresif Remaja, Kajian Sarjana Pendidikan (Psikologi), Universiti Teknologi Malaysia: Johor.

https://en.oxforddictionaries.com/definition/violence (accessed on 3/7/18) 